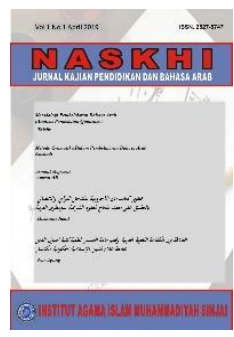

\title{
PENGARUH ILMU ASHWAT TERHADAP KETERAMPILAN BERBICARA MAHASISWA PENDIDIKAN BAHASA ARAB DI IAIM SINJAI
}

\author{
Amriani, Hardianto Rahman \\ Institut Agama Islam Muhammadiyah Sinjai \\ Amriani1801@gmail.com
}

\begin{abstract}
This research departs from a concern that not a few students can communicate using Arabic. However, the pronunciation does not correspond to the letter makhrojul so the listener does not understand what is spoken because the different pronunciations are different meanings. Therefore, this research aims to: prove the influence of ashwat science on IAIM Sinjai Arabic Language Education students. The method used in this study is quantitative research with a facto expost approach. The population was taken by 62 students from the Arabic Language Education study program with a sample taken of 51 people. The measurement scale uses the Likert scale. The results of this study show that: there is an influence of science on the speaking skills of IAI Arabic Language Education student Muhammadiyah Sinjai. Based on a simple regression analysis that has been done through the SPSS 20 program, obtained the result that of the 51 respondents studied known jikat-count $<$ $\mathrm{t}$-table, then $\mathrm{HO}$ is accepted. Ha is rejected, if $\mathrm{t}$-count $>\mathrm{t}$-table, then Ha is accepted, $\mathrm{H} 0$ is rejected. Based on the coefficients table that t-calculate 4,297 > t-table 1,676. Then it can be interpreted that the ashwat science variable (X) affects the speech skills variable (Y).
\end{abstract}

Keywords: Ashwat Science, Speaking Skills

\begin{abstract}
Abstrak
Penelitian ini berangkat dari sebuah keprihatinan dimana tidak sedikit mahasiswa yang bisa berkomunikasi dengan menggunakan bahasa Arab. Namun, pengucapannya tidak sesuai dengan makhrojul hurufnya sehingga pendengar tidak memahami apa yang dibicarakan karena beda pelafalan maka beda makna. Oleh karena itu, penelitian ini bertujuan untuk: membuktikan pengaruh ilmu ashwat terhadap mahasiswa Pendidikan Bahasa Arab IAIM Sinjai. Metode yang digunakan dalam penelitian ini adalah penelitian kuantitatif dengan pendekatan expost facto. Populasi yang diambil sejumlah 62 mahasiswa dari program studi Pendidikan Bahasa Arab dengan jumlah sampel yang diambil sebanyak 51 orang.Skala
\end{abstract}




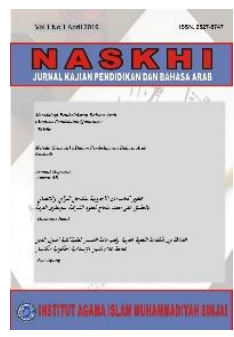

NASKHI

Jurnal Kajian Pendidikan dan Bahasa Arab

Volume 2, No. 2, 2020

ISSN (print) : 2527-5747

ISSN (online) : 2716-3369

Homepage : https://journal.iaimsinjai.ac.id/index.php/naskhi

pengukuran menggunakan skala Likert. Hasil penelitian ini menunjukkan bahwa: terdapat pengaruh ilmu ashwa tterhadap keterampilan berbicara mahasiswa Pendidikan Bahasa Arab IAI Muhammadiyah Sinjai. Berdasarkan analisis regresi sederhana yang telah dilakukan melalui program SPSS 20, diperoleh hasil bahwa dari 51 responden yang diteliti diketahui jikat-hitung $<\mathrm{t}$-tabel, maka $\mathrm{H}_{0}$ diterima. $\mathrm{H}_{\mathrm{a}}$ ditolak, jika t-hitung > t-tabel, maka $\mathrm{H}_{\mathrm{a}}$ diterima, $\mathrm{H}_{0}$ ditolak. Berdasarkan tabel coefficients bahwa t-hitung 4,297 > t-tabel 1,676. Maka dapat diartikan bahwa variabel ilmu ashwat (X) mempengaruhi variabel keterampilan berbicara (Y).

Kata Kunci: Ilmu Ashwat, Keterampilan Berbicara

\section{A. Pendahuluan}

Bahasa adalah realitas yang tumbuh dan berkembang sesuai dengan tumbuh kembangnya manusia pengguna bahasa itu. Realitas bahasa dalam kehidupan ini semakin menambah kuatnya eksistensi manusia sebagai makhluk berbudaya dan beragama. Kekuatan eksistensi manusia sebagai makhluk berbudaya dan beragama antara lain ditunjukkan oleh kemampuannya memproduksi karya-karya besar berupa sains, teknologi, dan seni yang tidak terlepas dari peran-peran bahasa yang digunakannya. Namun dalam konteks lain, bahasa bisa dijadikan alat propaganda, bahkan peperangan yang bisa membahayakan sesama jika pengguna bahasa tidak lagi melihat rambu-rambu agama dan kemanusiaan dalam penggunaannya (Hermawan, 2014).

Bahasa Arab menurut para linguistik berasal dari ras manusia dan rumpun bangsa yang mempunyai peran besar dalam sejarah peradaban kuno, yakni bangsa Semit. Kemudian keturunan mereka berpindah tempat meninggalkan tanah airnya dan menetap di lembah sungai Tigris dan Euphart sehingga membentuk rumpun bahasa dan bangsa kuno, termasuk di dalamnya Bahasa Ibrani (Izzuddin, 2018).

Bahasa Arab adalah serangkaian symbol-simbol yang tersusun sistematis sebagai perantara orang-orang Arab untuk menyampaikan maksud kepada lawan bicara mereka saat proses komunikasi berlangsung. Melalui pendekatan structural, Bahasa Arab dinilai sebagai sesuatu yang memiliki komponen-komponen kebahasaan, yaitu al-Ashwat, al-Mufrodat, dan atTarkib. Ketiga komponen tersebut dapat dipisahkan menjadi sebuah unsur yang berdiri sendiri,laiknya disiplin ilmu tertentu. Hal ini dikarenakan setiap komponen telah dikembangkan oleh ulama kontenporer hingga menjadi unsur bahasa yang bias diklasifikasikan menjadi beberapa subkeilmuan yang lebih kecil lagi. Dalam pendekatan tersebut, membelajarkan Bahasa berarti mengajarkan penguasaan terhadap koponen-komponen kebahasaannya (Rosyidi, 2009).

Salah satu pengetahuan yang diperlukan untuk memahami suatu bahasa adalah pengetahuan tentang posisi dan fungsi suara dalam bahasa juga 


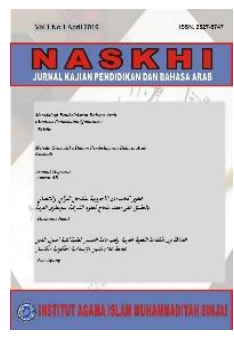

NASKHI

Jurnal Kajian Pendidikan dan Bahasa Arab

Volume 2, No. 2, 2020

ISSN (print) : 2527-5747

ISSN (online) : 2716-3369

Homepage : https://journal.iaimsinjai.ac.id/index.php/naskhi

bagaimana suara itu dirangkai Bersama untuk membentuk beberapa unit makna. Oleh karena itu, pengetahuan tentang suatu bahasa tidak dianggap lengkap dengan hanya memahami morfem, kata, frasa, dan kalimat saja, tanpa mengetahui bunyi bahasa Arab (Musthafa, 2017).

Di dalam pembelajaran bahasa Arab, al-Ashwat memegang peranan penting. Bahkan banyak literatur yang menyebutkan bahwa mempelajari dan mengkaji al-Ashwat wajib untuk didahulukan sebelum mempelajari dan mengkaji komponen dan keterampilan kebahasaan yang lainnya.

Aziz Syafruddin Syafrawi dan Hasan Saefuloh berpendapat dalam tulisan beliau bahwa pengajaran al-Ashwat sangat penting dalam pembelajaran bahasa Arab, karena al-Ashwat merupakan unsur pokok pada setiap Bahasa (Syafrawi, 2014).

Pemahaman dan penguasaan ilmu ashwat sangat berperan penting dalam keterampilan berbicara (maharah al-Kalam). Dengan pemahaman yang baik dan pelafalan yang fasih maka seseorang mampu memahamkan mitra bicaranya terhadap apa yang ia katakan. Jika keterampilan berbicara telah dikuasai maka proses komunikasi akan berjalan dengan lancar.

Poin yang penting adalah pemahaman ilmu ashwat sangat berpengaruh pada keterampilan berbahasa Arab. Keterampilan berbahasa tidak akan bisa dikuasai dengan sempurna jika pemahaman ilmu ashwat masih kurang. Oleh karena itu, pembelajaran ilmu ashwat sangat berpengaruh pada mahasiswa. Sebagai mahasiswa Fakultas Tarbiyah dan Ilmu Keguruan khususnya mahasiswa Pendidikan Bahasa Arab sudah selayaknya untuk mempelajari ilmu ashwat karena sebagai calon guru perlu mendalami materi ini agar kelak dapat diterapkan ketika sudah menjadi guru.

Tidak sedikit mahasiswa yang bisa berkomunikasi dengan menggunakan bahasa Arab. Namun, pengucapannya tidak sesuai dengan makhrojul hurufnya sehingga pendengar tidak memahami apa yang dibicarakan karena beda pelafalan maka beda makna. Motivasi dan minat mahasiswa yang rendah tersebut dalam melatih kemampuan berbicara dipengaruhi oleh berbagai faktor selain kurangnya penguasaan terhadap ilmu ashwat adalah penggunaan metode pengajaran yang tidak tepat, sehingga menjadikan mahasiswa semakin kesulitan mempelajari bahasa Arab (Agung, 2020)

Mengingat keterampilan berbicara sangat penting dalam pembelajaran bahasa Arab, yang selama ini terjadi kendala terutama dalam pengucapan saat berbicara maka pengaruh ilmu ashwat terhadap pembelajaran muhadatsah sangat penting untuk dikaji dan diteliti. Tulisan ini juga berfungsi untuk meminimalisir kesalahan dalam berbicara bahasa Arab.

\section{B. Metode Penelitian}

\section{Pendekatan Penelitian}

Jenis pendekatan yang digunakan dalam penelitian ini adalah penelitian kuantitatif. Penelitian kuantitatif dapat diartikan sebagai metode 


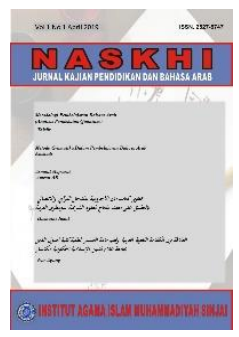

NASKHI

Jurnal Kajian Pendidikan dan Bahasa Arab

Volume 2, No. 2, 2020

ISSN (print) : 2527-5747

ISSN (online) : 2716-3369

Homepage : https://journal.iaimsinjai.ac.id/index.php/naskhi

penelitian yang berlandaskan pada fisafat positivisme, digunakan untuk meneliti pada populasi atau sampel tertentu, tekhnik pengambilan sampel pada umumnya dilakukan secara random, pengumpulan data menggunakan instrumen penelitian, analisis data bersifat kuantitatif/statistik dengan tujuan untuk menguji hipotesis yang telah ditetapkan (Sugiyono, 2016).

2. Teknik Pengumpulan Data

Teknik yang digunakan untuk mengumpulkan data penelitian adalah:

a. Angket (kuesioner), yaitu peneliti memberikan seperangkat pertanyaan atau pernyataan tertulis kepada responden untuk dijawabnya. Kuesioner merupakan teknik pengumpulan data yang efisien bila peneliti tahu dengan pasti variabel yang akan diukur dan tahu apa yang bisa diharapkan dari responden.

b. Dokumentasi, yaitu sumber data yang digunakan untuk melengkapi penelitian, baik berupa sumber tertulis maupun gambar.

\section{Sumber Data}

Data diperoleh dari analisis hasil angket yang diberikan kepada responden.

\section{PEMBAHASAN}

\section{Ilmu Ashwat}

Ilmu Ashwat adalah ilmu yang mempelajari tentang pembentukan, perpindahan dan penerimaan bunyi bahasa. Ilmu ashwat lebih popular dengan sebutan ilmu fonetik, yaitu suatu bidang linguistik yang menjelaskan dan menganalisa tentang pengucapan bunyi ujar yang membutuhkan praktek, bukan sekedar teori.

Ilmu bunyi yang dalam bahasa Arab diistilahkan dengan Ilmu $\mathrm{Al}$ Ashwat, yaitu ilmu yang mempelajari tentang pembentukan, perpindahan, dan penerimaan bunyi bahasa. Ilmu ini pada mulanya merupakan sebuah ilmu yang luas dan utuh yang di dalamnya terdapat beberapa cabang yang mempunyai bidang bahasan yang lebih focus (Nasution, 2010).

Al-Ashwat adalah suara, yaitu bagaimana kita mengucapkan bunyi suara dalam bahasa Arab dengan baik dan benar sebagaimana orang-orang Arab mrngucapkannya. Inti dari mempelajari al-Ashwat ini adalah kita bisa mengerti suara atau bunyi tersebut, bisa membedalan antara satu bunyi dengan yang lain dan bisa mengimplementasikannya dalam bentuk lain. Oleh karenanya diawal kita belajar bahasa Arab, kita akan sering dan terus berucap, berujar dan bahkan tidak jarang kita akan berteriak-teriak untuk melafalkan huruf, kata dan kalimat dalam bahasa Arab.

Pembelajaran bunyi bahasa (al-Ashwat) dimaksudkan adalah melatih peserta didik mengungkapkan bunyi huruf kata dan kalimat Arab serta perbedaan-perbedaan prinsipil secara benar dan fasih, sehingga mereka mampu untuk berinteraksi dan berkomunikasi secara intens. Dari konteks ini, maka 


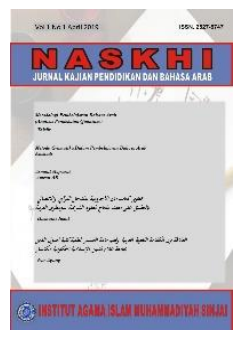

NASKHI

Jurnal Kajian Pendidikan dan Bahasa Arab

Volume 2, No. 2, 2020

ISSN (print) : 2527-5747

ISSN (online) : 2716-3369

Homepage : https://journal.iaimsinjai.ac.id/index.php/naskhi

tujuan pembelajaran bunyi bahasa (al-Ashwat) adalah membantu peserta didik mengucapkan dan mengekspresikan bunyi bahasa dengan fokus (Zulhannan, 2015)

a. Memahami unsur bunyi bahasa dan penggunaannya, seperti mengucapkan bunyi, stressing dan aksentuasi.

b. Penggunaan isyarat bahasa, seperti mengekspresikan wajah dan gerakangerakan.

c. Memahami penggunaan kata-kata yang mirip dan berdekatan.

d. Memahami konteks budaya yang diekspresikan dalam kalimat.

e. Membedakan konteks haqiqi dan konteks majazi.

f. Memahami struktur bahasa dan penggunaannya secara maksimal.

Mencermati tujuan pembelajaran bunyi bahasa di atas, maka dapat dipaparkan berikut teknik pembelajarannya secara konkret (Zulhannan, 2015)

a. Pendidik dan peserta didik melakukan repetisi sesuatu huruf-huruf Arab) melalui tiga proses repetisi (repetisi kolektif, kelompok, dan individu).

Repetisi kolektif dilakukan seluruh peserta didik, selanjutnya repetisi kelompok dilakukan kelompok yang telah didesain, kemudian repetisi individu dilakukan oleh individu yang ditunjuk oleh pendidik.

b. Pendidik mengucapkan contoh yang ditampilkan dua atau tiga kali, sedangkan peserta didik mendengarkan.

c. Pendidik memberikan isyarat, kemudian peserta didik diminta untuk merepetisi secara kolektif.

d. Pendidik merepetisi isyarat tadi, kemudian diikuti peserta didik secara kolektif.

e. Pendidik memberikan isyarat, kemudian peserta didik diminta untuk merepetisi secara kelompok.

f. Pendidik merepetisi isyarat tadi,kemudian diikuti peserta didik secara kelompok.

g. Pendidik memberikan isyarat, kemudian peserta didik diminta untuk merepetisi secara individu.

h. Pendidik merepetisi isyarat tadi, kemudian diikuti peserta didik secara individu. Dalam proses repetisi individu, pendidik memerhatikan respons peserta didik. Jika memungkinkan untuk diadakan perbaikan, atau diberikan motivasi bahkan diberikan pujian, maka hal tersebut harus dilakukan sebagai stimulus mereka mempelajari bahasa Arab.

\section{Keterampilan Berbicara}

Keterampilan berbicara (maharah al-kalam/ speaking skill) adalah kemampuan mengungkapkan bunyi-bunyi artikulasi atau kata-kata untuk mengekspresikan pikiran berupa ide, pendapat, keinginan, atau perasaan kepada mitra bicara. Keterampilan berbicara dalam pada dasarnya keterampilan produktif, yaitu hasil proses dari pembelajaran beberapa bidang 


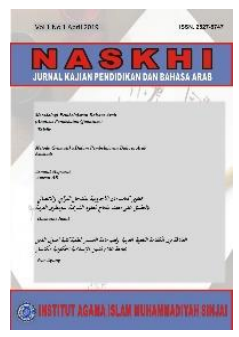

NASKHI

Jurnal Kajian Pendidikan dan Bahasa Arab

Volume 2, No. 2, 2020

ISSN (print) : 2527-5747

ISSN (online) : 2716-3369

Homepage : https://journal.iaimsinjai.ac.id/index.php/naskhi

atau aspek bahasa Arab (Munir, 2017). Untuk dapat mempunyai keterampilan berbicara dalam bahasa Arab maka perlu kita ketahui ilmu ashwat.

Keterampilan berbicara dianggap sebagai keterampilan yang sangat penting dalam pembelajaran bahasa asing, karena berbicara merupakan suatu yang aplikatif dalam bahasa dan merupakan tujuan awal seseorang yang belajar suatu bahasa. Hanya saja, yang perlu diperhatikan dalam pembelajaran berbicara ini agar memperoleh hasil yang maksimal yaitu kemampuan dari seorang dosen dan metode yang digunakannya, karena dua faktor tersebut memiliki dominasi keberhasilan pembelajaran berbicara.

Menurut Abu Bakar, tujuan dari keterampilan atau kemahiran berbicara adalah sebagai berikut (Nuha, 2012).

a. Membiasakan murid bercakap-cakap dengan bahasa yang fasih.

b. Membiasakan murid menyusun kalimat yang timbul dari dalam hati dan perasaannya dengan kalimat yang benar dan jelas.

c. Membiasakan murid memilih kata dan kalimat, lalu menyusunnya dalam bahasa yang indah, serta memperhatikan penggunaan kata pada tempatnya.

Berbicara menggunakan bahasa asing bukanlah hal yang mudah, sebagaimana jika berbicara menggunakan bahasa ibu. Oleh karena itu, hendaknya dalam mengajarkan keterampilan berbicara (maharah al-kalam) perlu memperhatikan Teknik pengajaran yang sesuai dengan kemampuan anak didik. Harus diakui bahwa tidak semua orang mampu dengan baik dan sempurna dalam berbicara menggunakan bahasa asing, termasuk dalam bahasa Arab. Diantara mereka, ada yang mempunyai penguasaan bahasa asing sangat bagus, ada yang sederhana, dan ada yang masih sangat pemula, bahkan ada yang sama sekali belum bisa. Oleh karena itu, dalam pembelajarannya, hendaknya terdapat spesifikasi Teknik yang bisa dipakai oleh pemula, menengah, dan tingkat tinggi (ahli). Diantara Teknik tersebut adalah sebagai berikut (Nuha, 2012)

a. Tingkat Pemula

Bagi tingkat pemula, dapat digunakan Teknik ulang uca, lihat ucap, permainan kartu kata, wawancara, permainan memori, reka cerita gambar, biografi, manajemen kelas, bermain peran, permainan telepon, dan permainan alphabet.

b. Tingkat Menengah

Untuk tingkat menengah, dapat digunakan teknik-teknik dramatisasi, elaborasi, reka cerita gambar, biografi, permainan memori, wawancara, permainan kartu kata, diskusi, permainan telepon, percakapan satu pihak, piato pendek, paraphrase, melanjutkan cerita, dan permainan alphabet.

c. Tingkat Paling Tinggi

Sedangkan untuk tingkat paling tinggi, dapat digunakan teknikteknik dramatisasi, elaborasi, reka cerita gambar, biografi, permainan 


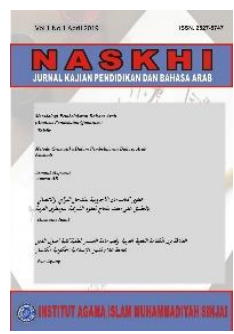

NASKHI

Jurnal Kajian Pendidikan dan Bahasa Arab

Volume 2, No. 2, 2020

ISSN (print) : 2527-5747

ISSN (online) : 2716-3369

Homepage : https://journal.iaimsinjai.ac.id/index.php/naskhi

memori, diskusi, wawancara, pidato, melanjutkan cerita, talk show, paraphrase, dan debat.

\section{Pengaruh Ilmu Ashwat Terhadap Keterampilan Berbicara Mahasiswa}

Terdapat pengaruh ilmu Ashwat tethadap keterampilan berbicara mahasiswa Pendidikan Bahasa Arab IAI Muhammadiyah Sinjai dibuktikan bahwa:

a. Berdasarkan hasil analisis regresi sederhana yang telah dilakukan melalui program SPSS 20, diperoleh hasil bahwa dari 51 responden di program studi Pendidikan Bahasa Arab IAI Muhammadiyah Sinjai pada tabel cofficients diketahui t-hitung ilmu ashwat secara signifikan berpengaruh terhadap keterampilan berbicara mahasiswa Pendidikan Bahasa Arab IAI Muhammadiyah Sinjai, sedangkan pada nilai probabilitas $0,000<0,05$ maka ilmu ashwat memiliki pengaruh terhadap keterampilan berbicara mahasiswa Pendidikan Bahasa Arab IAI Muhammadiyah Sinjai.

b. Untuk mengetahui besaran pengaruh antara ilmu ashwat terhadap keterampilan berbicara mahasiswa dapat dilihat pada tabel model summary dengan melihat R Square= 0,274 atau 27,4\% jadi besar pengaruh ilmu ashwat terhadap keterampilan berbicara mahasiswa Pendidikan Bahasa Arab IAI Muhammadiyah Sinjai adalah 27,4\% dengan kata lain terdapat aspek-aspek selebihnya yang memiliki pengaruh keterampilan berbicara mahasiswa Pendidikan Bahasa Arab IAI Muhammadiyah Sinjai.

Dari kedua pengujian hipotesis tersebut bahwa antara ilmu ashwat terhadap keterampilan berbicara mahasiswa. Dalam hal ini telah dibuktikan dengan melakukan penelitian di mahasiswa Pendidikan Bahasa Arab IAI Muhammadiyah Sinjai, sehingga hasil penelitian tersebut dapat disimpulkan bahwa ilmu ashwat memiliki pengaruh positif dan signifikan dengan keterampilan berbicara mahasiswa Pendidikan Bahasa Arab IAI Muhammadiyah Sinjai.

\section{PENUTUP}

Dari hasil analisis angket, maka dapat ditarik kesimpulan bahwa terdapat pengaruh ilmu ashwat terhadap keterampilan berbicara mahasiswa Pedidikan Bahasa Arab IAI Muhammadiyah Sinjai. Berdasarkan hasil analisis regresi sederhana yang telah dilakukan melalui program SPSS 20, diperoleh hasil dari responden yang diteliti di program studi Pendidikan Bahasa Arab IAI Muhammadiyah Sinjai yang terdiri dari tiga angkatan yaitu angkatan 2017 sebanyak 10 orang, angkatan 2018 sebanyak 14 orang, dan angkatan 2019 sebanyak 27 orang dengan total responden sebanyak 51 orang. Diketahui jika thitung $\leq \mathrm{t}$-tabel maka $\mathrm{H}_{0}$ diterima dan $\mathrm{H}_{\mathrm{a}}$ ditolak, jika t-hitung $>\mathrm{t}$-tabel maka $\mathrm{H}_{0}$ ditolak dan $\mathrm{H}_{\mathrm{a}}$ diterima. Berdasarkan tabel coefficients bahwa t-hitung $(4,297)>$ t-tabel $(1,676)$ dan nilai probabilitas $0,000<0,05$ dan pada tabel model summary dengan melihat $\mathrm{R}$ Square $=0,274$ atau $27,4 \%$ maka dapat diartikan bahwa variabel ilmu ashwat (X) mempengaruhi variabel keterampilan 


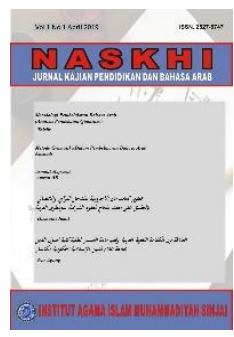

NASKHI

Jurnal Kajian Pendidikan dan Bahasa Arab

Volume 2, No. 2, 2020

ISSN (print) : 2527-5747

ISSN (online) : 2716-3369

Homepage : https://journal.iaimsinjai.ac.id/index.php/naskhi

berbicara mahasiswa Pendidikan Bahasa Arab IAI Muhammadiyah Sinjai (Y) sebesar $27,4 \%$.

\section{E. DAFTAR PUSTAKA}

Agung, N. (2020). Peningkatan Kemampuan Debat Bahasa Arab Mahasiswa Melalui Metode Suggestopedia. Jurnal Naskhi: Jurnal Kajian Pendidikan Dan Bahasa Arab, 2(1), 19-29. Retrieved from https://journal.iaimsinjai.ac.id/index.php/naskhi\%0APENINGKATAN

Hermawan, A. (2014). Metodologi Pembelajaran Bahasa Arab. Bandung: Remaja Rosdakarya.

Izzuddin, M. (2018). Metodologi Penelitian Bahasa Arab Konsep Dasar Strategi Metode Teknik. Bandung: Remaja Rosdakarya.

Munir. (2017). Perencanaan Sistem Pengajaran Bahasa Arab Teori dan Prektik. Jakarta: Kencana.

Musthafa, S. (2017). Strategi Pembelajaran Bahasa Arab Inovatif. Malang: UINMalang Press.

Nasution, A. S. (2010). Bunyi Bahasa Ilm Al-Ashwat Al-Arabiyyah. Jakarta: Amzah.

Nuha, U. (2012). Metodologi Super Efektif Pembelajaran Bahasa Arab. Yogyakarta: Diva Press.

Rosyidi, A. W. (2009). Media Pembelajaran Bahasa Arab. Malang: UIN-Malang Press.

Sugiyono. (2016). Metode Penelitian \& Pengembangan Reseach and Development (2nd ed.). Bandung: Alfabeta.

Syafrawi, A. S. (2014). Pembelajaran Tata Bunyi (Ashwat) Bahasa Arab, Jurnal. Zulhannan. (2015). Teknik Pembelajaran Bahasa Arab Interaktif. Jakarta: Rajawali Press. 